University of Nebraska - Lincoln

DigitalCommons@University of Nebraska - Lincoln

\title{
Differential induction of redox sensitive extracellular phenolic amides in potato
}

C. Jacyn Baker

United States Department of Agriculture, jacyn.baker@ars.usda.gov

Bruce D. Whitaker

United States Department of Agriculture

Norton M. Mock

United States Department of Agriculture

Clifford P. Rice

United States Department of Agriculture

Daniel P. Roberts

United States Department of Agriculture, dan.roberts@ars.usda.gov

See next page for additional authors

Follow this and additional works at: https://digitalcommons.unl.edu/usdaarsfacpub

Part of the Agricultural Science Commons

Baker, C. Jacyn; Whitaker, Bruce D.; Mock, Norton M.; Rice, Clifford P.; Roberts, Daniel P.; Deahl, Kenneth L.; Ueng, Peter P.; and Aver'yanov, Andrey A., "Differential induction of redox sensitive extracellular phenolic amides in potato" (2009). Publications from USDA-ARS / UNL Faculty. 384.

https://digitalcommons.unl.edu/usdaarsfacpub/384

This Article is brought to you for free and open access by the U.S. Department of Agriculture: Agricultural Research Service, Lincoln, Nebraska at DigitalCommons@University of Nebraska - Lincoln. It has been accepted for inclusion in Publications from USDA-ARS / UNL Faculty by an authorized administrator of DigitalCommons@University of Nebraska - Lincoln. 


\section{Authors}

C. Jacyn Baker, Bruce D. Whitaker, Norton M. Mock, Clifford P. Rice, Daniel P. Roberts, Kenneth L. Deahl, Peter P. Ueng, and Andrey A. Aver'yanov 


\title{
Differential induction of redox sensitive extracellular phenolic amides in potato
}

\author{
C. Jacyn Baker ${ }^{\mathrm{a}, *}$, Bruce D. Whitaker ${ }^{\mathrm{c}}$, Norton M. Mock ${ }^{\mathrm{a}}$, Clifford P. Rice ${ }^{\mathrm{b}}$, Daniel P. Roberts ${ }^{\mathrm{d}}$, \\ Kenneth L. Deahl ${ }^{\mathrm{e}}$, Peter P. Ueng ${ }^{\mathrm{a}}$, Andrey A. Aver'yanov ${ }^{\mathrm{f}}$ \\ a Molecular Plant Pathology Lab., US Department of Agriculture, Beltsville, MD 20705, USA \\ ${ }^{\mathrm{b}}$ Environmental Quality Lab., US Department of Agriculture, Beltsville, MD 20705, USA \\ ${ }^{c}$ Produce Quality and Safety Lab., US Department of Agriculture, Beltsville, MD 20705, USA \\ d Sustainable Agricultural Systems Lab., US Department of Agriculture, Beltsville, MD 20705, USA \\ e Vegetable Lab, US Department of Agriculture, Beltsville, MD 20705, USA \\ ${ }^{\mathrm{f}}$ Research Institute of Phytopathology, B. Vyazemy, Moscow region 143050, Russia
}

\section{A R T I C L E I N F O}

\section{Article history:}

Accepted 18 March 2009

\section{Keywords:}

Apoplast

Phenolic amides

Tyramine

Pseudomonas syringae

Ralstonia solanacearum

Hydroxycinnamic acid amides

Coumaroyloctopamine

Feruloyloctopamine

\begin{abstract}
A B S T R A C T
This study focuses on the differential induction of extracellular phenolic amides that accumulate in potato cell suspensions during the first few hours of the interaction between these plant cells and either bacterial pathogens or pathogen-related elicitors. Using suspension cells of Solanum tuberosum we identified 4 hydroxycinnamic acid amides that accumulate in the extracellular environment. Treatment of the suspension cells with pathovars of the plant pathogens Pseudomonas syringae or Ralstonia solanacearum or with pathogen-related elicitors changed the composition of the extracellular phenolic amides within hours and the composition differed for each treatment. Some of the phenolic amides were sensitive to oxidative stress; when suspension cells were treated with bacterial strains or elicitors that triggered an oxidative burst, the phenolics were oxidized and depleted for the duration of the burst. Other critical parameters that affected the qualitative and quantitative makeup of these phenolic amides were plant cell age and density.
\end{abstract}

Published by Elsevier Ltd.

\section{Introduction}

The apoplast matrix that surrounds the plant cell is a dynamic microenvironment that mediates communication between the cell and its surroundings and is often the first line of defense against invading pathogens. One of the first plant responses to pathogen invasion is an increase in a wide array of secondary metabolites, many of which can be detected in the apoplast shortly after pathogen contact. These metabolites serve many roles including cell wall reinforcement, antimicrobial toxicity, and bioactive influence on the plant/pathogen interaction. Plant cell suspensions offer a useful model system to help gain insight into apoplastic phenomena $[12,15]$. The cells maintain a pseudo-apoplast environment within the cell wall matrix that is continually in flux with the suspension medium. In tobacco, we demonstrated the increase in hydroxycinnamic acid derivatives several hours after inoculation with pathogenic bacteria and how these metabolites can be

\footnotetext{
* Corresponding author. Molecular Plant Pathology Lab., Bldg. 004 Rm. 119, US Department of Agriculture, Beltsville, MD 20705, USA. Tel.: +1 301504 5617; fax: +1 3015045449

E-mail address: jacyn.baker@ars.usda.gov (C.J. Baker).
}

oxidized by the oxidative burst associated with resistant interactions [5,7]. One compound, acetosyringone, was shown to have a bioactive effect on the plant/bacterial interaction, affecting the timing of early physiological responses [6].

In this study with potato suspension cells, we found the major soluble extracellular phenolics that accumulated were hydroxycinnamic acid (HCA) amides. The increase of soluble and cell-wall bound phenolic amides as a result of various stresses is well documented $[10,13,15,17,20]$. The synthesis of these metabolites appears to involve phenylalanine ammonia lyase (PAL), which is stress induced and leads to hydroxycinnamic acid moieties including CoA thio esters. The condensation of the CoA thioester with the amine moiety appears to be carried out by amine specific transferases $[9,10]$. This has been best demonstrated for tyramine conjugates, tyramine is produced by the action of tyrosine decarboxylase (TDC) and the product is transferred to the hydroxycinnamoyl-CoA thioester by tyraminehydroxycinnamoyltransferase (THT) [10,11,20,22].

In this study, we report the hourly change in potato secondary metabolites in response to pathogens or pathogen-related elicitors. Previous studies reported changes that occurred many hours or days after various treatments. We have been studying the release of extracellular phenolics in potato suspension cells in relation to the presence of pathogens and the often associated oxidative burst. 
Here we report in potato suspension cells a more differential induction of the extracellular phenolic amides in regard to the bacterial pathogens at a time early enough to have a bioactive influence on the interaction.

\section{Materials and methods}

\subsection{Chemicals}

Horseradish peroxidase (P-8250), luminol (5 amino-2,3-dihydro1,4-phthalazinedine; A8511), hydrogen peroxide (H1009) and all other chemicals were purchased from Sigma-Aldrich Chemicals Inc. (St. Louis, MO), unless otherwise noted.

\subsection{Plant material}

Potato (Solanum tuberosum cv. Kennebec) suspension and callus cultures are maintained on B5 media (Sigma G5768) supplemented with sucrose $20 \mathrm{~g} \mathrm{l}^{-1}$; $\mathrm{MgSO}_{4}, 6.9 \mathrm{mg} \mathrm{l}^{-1}$; myo-inositol, $0.1 \mathrm{mg} \mathrm{l}^{-1}$; 2,4-D $0.5 \mathrm{mg} \mathrm{l}^{-1}$; casein $2 \mathrm{mg} \mathrm{l}^{-1}$; thiamine $10 \mathrm{mg} \mathrm{l}^{-1}$; pyridoxine $1 \mathrm{mg} \mathrm{l}^{-1}$; nicotine $1 \mathrm{mg} \mathrm{l}^{-1}$; pH 5.83. Every 7 days $13 \mathrm{ml}$ of suspension culture were transferred to $80 \mathrm{ml}$ of fresh media. Routinely, 5-days-old potato cultures were used for assays. Cells were washed and suspended at a cell density of $0.05 \mathrm{~g} / \mathrm{ml}$ in assay buffer $\left(0.5 \mathrm{mM} \mathrm{CaCl}_{2}, 0.5 \mathrm{mM} \mathrm{K}_{2} \mathrm{SO}_{4}, 175 \mathrm{mM}\right.$ mannitol and $0.5 \mathrm{mM}$ MES, pH 6). The cell suspensions, $25 \mathrm{ml}$, in $50 \mathrm{ml}$ beakers, were equilibrated for $0.5 \mathrm{~h}$ prior to treatment in a rotary water bath shaker at $27^{\circ} \mathrm{C}$ and $190 \mathrm{rpm}$. Treatments were added directly to the suspensions. The viability of potato cells remained constant during the $7 \mathrm{~h}$ monitoring period of these experiments as estimated by Evans Blue staining [3]. All experiments were performed at least twice with two or more replicates per treatment.

\subsection{Bacterial and fungal preparations}

Isolates of Pseudomonas syringae pv. syringae 61 (Pss), P. syringae pv. tabaci, and Ralstonia solanacearum, were maintained on Kings B agar [8]. Pss isolate WT(HR+), which causes a hypersensitive reaction in potato, was supplemented with nalidixic acid $(25 \mu \mathrm{g} / \mathrm{ml})$; Pss B7(HR-), containing a single Tn5 insertion and does not induce a hypersensitive response in potato [1], was supplemented with nalidixic acid $(25 \mu \mathrm{g} / \mathrm{ml})$ and streptomycin $(40 \mu \mathrm{g} / \mathrm{ml})$. Prior to use, bacterial cultures were grown for $20 \mathrm{~h}$ in Kings B broth, centrifuged, washed and suspended in deionized water. Based on optical density, the concentration of the bacterial inoculum was adjusted with sterilized deionized water so that addition of about $200 \mu \mathrm{L}$ to potato cell suspensions would result in a final bacterial concentration of $10^{7} \mathrm{cfu} \mathrm{ml}^{-1}$, unless otherwise noted. Bacterial concentrations in potato cell suspensions were verified periodically by dilutionplating. Heat-killed preparations (HKWT) of Pss WT(HR+) were prepared as above and then autoclaved 20 min prior to treating cell suspensions.

The fungal elicitor was prepared from Phytophthora infestans grown 3-4 weeks at $18 \mathrm{C}$ in still cultures in the synthetic medium as described by Kamoun et al. [14].

\subsection{HPLC-UV quantification phenolics}

One-milliliter samples of potato cell suspensions were filtered through Miracloth and centrifuged at $12000 \mathrm{~g}$ for $5 \mathrm{~min}$ prior to HPLC analysis. When not analyzed immediately, samples were flushed with $\mathrm{N}_{2}$ and stored overnight at $-20^{\circ} \mathrm{C}$. Phenolics were separated by $\mathrm{C}_{18}$ RP-HPLC using a Waters (Milford, MA) quaternary pump, autosampler, photodiode array detector, and Empower data acquisition on a Dell Pentium 4 computer. A $250 \times 4.6 \mathrm{~mm}$ i.d., $5 \mu \mathrm{m}$
Luna C18(2) analytical column (Phenomenex, Torrence, CA) was used with a binary mobile phase gradient of methanol in $0.01 \%$ aqueous phosphoric acid as previously described [5]. Aliquots, $100 \mu \mathrm{L}$, of samples were acidified with phosphoric acid $(0.1 \%)$ and placed in the autosampler using a $40 \mu \mathrm{L}$ injection volume. Quantification of peak area was preformed using the UVmax wavelength for each peak and reported as relative HPLC units.

\subsection{Identification of phenolics}

Atmospheric pressure ionization mass spectrometry analysis was performed on a Quattro LC benchtop triple quadruple mass spectrometer (Micromass Ltd., Manchester, UK) using the electrospray ionization interface in the negative mode $\left(\mathrm{ES}^{-}\right)$as previously described [23]. Mass spectrometric data were acquired in the full scan mode over the $m / z 50-400$ range. Sensitivity of the mass spectrometer was optimized using an acetosyringone standard. A Waters 2690 HPLC system using the same column and gradient as described for HPLC-UV analysis was utilized for separation of the phenolics. Samples of potato suspensions for mass spectroscopy were prepared as for HPLC-UV followed by acidification with phosphoric acid (0.1\%) and extraction with ethyl acetate. Dried samples were dissolved in methanol-water, $(1: 1, \mathrm{v} / \mathrm{v})$ plus $0.1 \%$ formic acid, and $20 \mu \mathrm{L}$ injected per run with a Waters autosampler.

Phenolics isolated by HPLC-UV were dissolved in $0.8 \mathrm{ml}$ of $\mathrm{CD}_{3} \mathrm{OD}$, and ${ }^{1} \mathrm{H}$ NMR spectra were acquired deuterium locked at $25{ }^{\circ} \mathrm{C}$ using a Bruker QE $300 \mathrm{MHz}$ NMR spectrometer. Chemical shift values were assigned relative to the frequencies of residual nondeuterated water and methanol externally referenced to tetramethylsilane (TMS).

\subsection{Extracellular antioxidant assay}

The extracellular antioxidant capacity was estimated using a chemiluminescent assay that determined the quantity of $\mathrm{H}_{2} \mathrm{O}_{2}$ consumed by samples [4]. Samples $(0.4 \mathrm{ml})$ of treated or untreated suspension cells were dispensed into tubes, and placed into an EG\&G Berthold Autolumat 953 luminometer (Bad Wildbad, Germany). Two stock solutions were prepared: A) $0.5 \mathrm{mM} \mathrm{H}_{2} \mathrm{O}_{2}$ in the same assay buffer used for cell suspensions; and $\mathrm{B}$ ) horseradish peroxidase, $28.8 \mathrm{U} / \mathrm{ml}$, and $1.71 \mathrm{mM}$ luminol in $1 \mathrm{M} \mathrm{NaPO}_{4}, \mathrm{pH} 7$. The luminometer first added stock solution A $(50 \mu \mathrm{L})$ followed $4.5 \mathrm{~s}$ later by stock solution $\mathrm{B}(50 \mu \mathrm{L})$. The final concentrations were $50 \mu \mathrm{M} \mathrm{H}_{2} \mathrm{O}_{2}, 1.44 \mathrm{U} / \mathrm{ml}$ of peroxidase and $171 \mu \mathrm{M}$ luminol. Chemiluminescence was measured as relative light units (RLU) every $0.1 \mathrm{~s}$ for $20 \mathrm{~s}$; the maximum measurement is proportional to the $\mathrm{H}_{2} \mathrm{O}_{2}$ concentration. Standard curves were prepared with dilutions of $\mathrm{H}_{2} \mathrm{O}_{2}$ in assay buffer. Under these assay conditions, the extracellular antioxidant in each sample had sufficient time to react with the added $\mathrm{H}_{2} \mathrm{O}_{2}$; the remaining $\mathrm{H}_{2} \mathrm{O}_{2}$ reacted with luminol. The decrease in RLU in suspension samples compared to buffer controls corresponds to the $\mathrm{H}_{2} \mathrm{O}_{2}$ consumed by extracellular antioxidant in each sample and provides an estimate of the extracellular antioxidant concentration of each sample.

\section{Results and discussion}

\subsection{Identification of extracellular phenolics}

The eight phenolics from $S$. tuberosum cell cultures were identified as $Z$ and $E$ isomers of four HCA amides (Table 1). The four $E$ isomers (shown in Fig. 1) were much more abundant than the corresponding $Z$ isomers, which reportedly arise via photo-induced isomerization of the natural $E$ isomers [19], and are therefore not considered further in the results. Peak pairs 1 and 3, 2 and 4, 5 and 
Table 1

Hydroxycinnamic acid (HCA) amide conjugates released from cultured cells of S. tuberosum and quantified by HPLC-UV analysis.

\begin{tabular}{|c|c|c|c|c|}
\hline & Elution time (min) & UV abs. maxima (210-330 nm) & $\mathrm{ES}^{-}-\mathrm{MS}$ ions $[\mathrm{M}-1]^{-} 100 \% \mathrm{RI}^{\mathrm{a}}$ & Identification \\
\hline Peak 1 & 24.3 & 272 & 298280 & $N$-(Z)-p-coumaroyloctopamine \\
\hline Peak 2 & 25.1 & $275,302(\mathrm{sh})$ & 328310 & $N$-(Z)-feruloyloctopamine \\
\hline Peak 3 & 26.5 & 308 & 298280 & $N$-(E)-p-coumaroyloctopamine \\
\hline Peak 4 & 27.0 & 319, 293(sh) & 328310 & $N$-(E)-feruloyloctopamine \\
\hline Peak 5 & 28.5 & $276,304(\mathrm{sh})$ & 312312 & $N$-(Z)-feruloyltyramine \\
\hline Peak 6 & 29.5 & $276,304(\mathrm{sh})$ & 342310 & $N-(Z)$-feruloyl-4'-O- methyloctopamine ${ }^{b}$ \\
\hline Peak 7 & 30.9 & $318,292(\mathrm{sh})$ & 312312 & $N$-(E)-feruloyltyramine \\
\hline Peak 8 & 31.7 & $319,293(\mathrm{sh})$ & 342310 & $\mathrm{~N}-(E)$-feruloyl-4'-O- methyloctopamine ${ }^{\mathrm{b}}$ \\
\hline
\end{tabular}

${ }^{\mathrm{a}} \mathrm{RI}=$ relative intensity.

b Tentative identification based on HPLC, LC-MS, and UV absorbance data.

7, and 6 and 8 had identical ES ${ }^{-}-\mathrm{MS}$ spectra but very different UV spectra, which showed the first compound in each pair (peaks 1, 2, 5 and 6 ) to be the $Z$ isomer and the second compound (peaks 3, 4, 7 and 8 ) to be the corresponding $E$ isomer [19]. The HPLC elution times, ES $^{-}$-MS spectra, and UV spectra of $S$. tuberosum peaks 5 and 7 were identical to $N$-(Z)-feruloyltyramine and $N$-(E)-feruloyltyramine (Fig. 1), as identified in a previous study [5]. In the $\mathrm{ES}^{-}-\mathrm{MS}$ spectra of peaks 2 and $4,[\mathrm{M}-1]^{-}$was at $m / z 328$, indicating that these HCA amide isomers differ from $N$-feruloyltyramine by the addition of one oxygen atom. This, as well as the base-peak ion at $\mathrm{m} / \mathrm{z} 310$ (reflecting a ready loss of $\mathrm{H}_{2} \mathrm{O}$ ), is consistent with
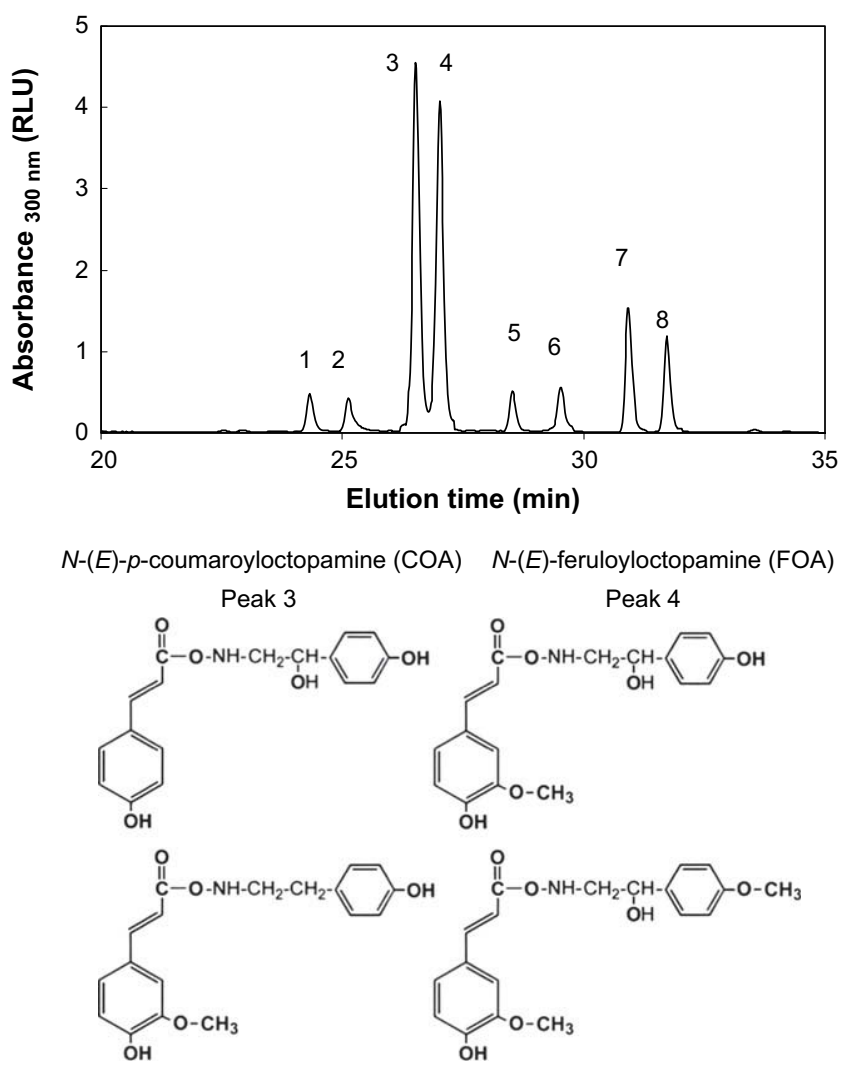

$N$-(E)-feruloyltyramine (FTA) $\quad \mathrm{N}$-(E)-feruloyl-4'-O-methyloctopamine (FMOA) Peak 7

$$
\text { Peak } 8
$$

Fig. 1. HPLC-UV chromatogram and structures of the extracellular hydroxycinnamic acid amide (HCA) conjugates that accumulate in potato cell suspensions. The chromatogram is a composite of several samples in order to include all of the phenolics in a single chromatogram. The numbering of the HPLC peaks corresponds to Table 1 : peak 1 and 3, the $Z$ and $E$ isomers, respectively, of $\mathrm{N}$-p-coumaroyloctopamine; peak 2 and 4 , the $Z$ and $E$ isomers, respectively, of $\mathrm{N}$-feruloyloctopamine; peak 5 and 7 , the $Z$ and $E$ isomers, respectively, of $\mathrm{N}$-feruloyltyramine; peak 6 and 8, the $Z$ and $E$ isomers, respectively, of $\mathrm{N}$-feruloyl-4'-O-methyloctopamine. The structures of the $E$ isomers are shown. identification of these two phenolics as $N$-(Z)-feruloyloctopamine and $N$-(E)-feruloyloctopamine $\left(\mathrm{C}_{18} \mathrm{H}_{19} \mathrm{NO}_{5}=329\right.$; Fig. 1). Peaks 1 and 3 were identified as $N-(Z)$-p-coumaroyloctopamine and $N-(E)$ p-coumaroyloctopamine $\left(\mathrm{C}_{17} \mathrm{H}_{17} \mathrm{NO}_{4}=299\right.$; Fig. 1$)$ by the following criteria: $[\mathrm{M}-1]^{-}$was at $m / z 298$ and the base-peak ion was at $m / z$ 280 , analogous to $\mathrm{N}$-feruloyloctopamine but 30 Da lower, suggesting the substitution of a proton for a methoxy group at C-3 of the HCA phenyl ring. Consistent with this, the UV spectrum of peak 3 (maximum at $308 \mathrm{~nm}$ ) indicated the inclusion of a $(E)$-p-coumaroyl moiety in the structure. Identification of peaks 6 and 8 is less certain, but the $\mathrm{UV}$ and $\mathrm{ES}^{-}-\mathrm{MS}$ spectra support the conclusion that they are $Z$ and $E$ isomers of $N$-feruloyl-4'-O-methyloctopamine (Fig. 1). Specifically, the UV spectrum of peak 8 was closely similar to those of $N-(E)$-feruloyltyramine and $N-(E)$-feruloyloctopamine, indicating that peak 8 is an $N-(E)$-feruloylamide; the $[\mathrm{M}-1]^{-}$ion from peaks 6 and 8 was at $m / z 342$, consistent with O-methylation of $\mathrm{N}$-feruloyloctopamine and the formula $\mathrm{C}_{19} \mathrm{H}_{21} \mathrm{NO}_{5}=343$; and finally, the base-peak ion was at $m / z 310$, identical to that from $\mathrm{N}$-feruloyloctopamine and indicative of the loss of one hydroxyl and one methyl group.

\subsection{Phenolic accumulation in suspensions treated with bacterial isolates}

\subsubsection{P. syringae $p v$. syringae isolates}

The response of potato suspension cells, $0.05 \mathrm{~g} \mathrm{ml}^{-1}$, to Pss $\mathrm{WT}(\mathrm{HR}+)$ and $\mathrm{B} 7(\mathrm{HR}-)$, which do and do not cause an oxidative burst, respectively, was followed over a $7 \mathrm{~h}$ period using an inoculum concentration of $10^{7} \mathrm{cfu} \mathrm{ml}^{-1}$. The accumulation of extracellular phenolics was monitored using UV-HPLC analysis (Fig. 2A). The detection of an oxidative burst was accomplished by the periodic sampling of the total extracellular antioxidant capacity (Fig. 2B), which decreases during an oxidative burst [4].

The extracellular phenolics in all of the potato suspension treatments did not accumulate substantially during the first $2 \mathrm{~h}$ period (Fig. 2A), which coincided with an oxidative burst resulting from the preparation of the cell suspensions (Fig. 2B). Previous studies have demonstrated that many extracellular phenolics act as antioxidants and are oxidized during periods of oxidative stress $[4,5]$. After about $1.5 \mathrm{~h}$ the initial oxidative burst appeared to end and the control and $\mathrm{B} 7(\mathrm{HR}-)$ treatments immediately started to increase in antioxidant capacity, while the Pss WT(HR+) treatment was delayed about $1 \mathrm{~h}$. After this initial period, the control cell suspensions and Pss B7(HR-) treatment increased in extracellular phenolics and antioxidant capacity for the remainder of the $7 \mathrm{~h}$ monitoring period. The potato suspensions treated with PSS $\mathrm{WT}(\mathrm{HR}+)$ increased in antioxidant capacity after about $2.5 \mathrm{~h}$ at a similar rate to the other treatments, however, a second much larger oxidative burst started at about $3.5 \mathrm{~h}$ and peaked at about $5 \mathrm{~h}$ (Fig. 2B). This coincided with much lower concentrations of 

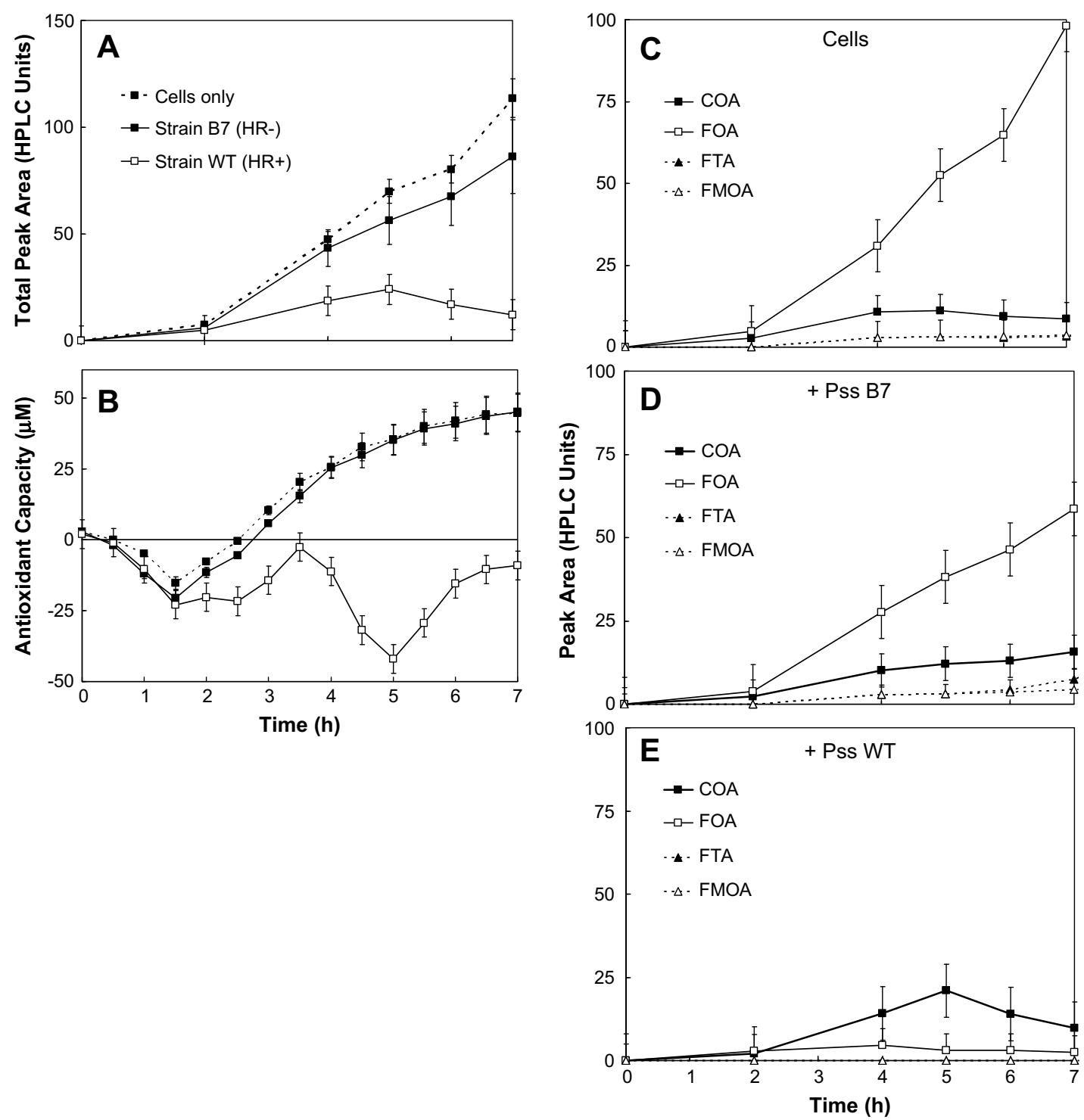

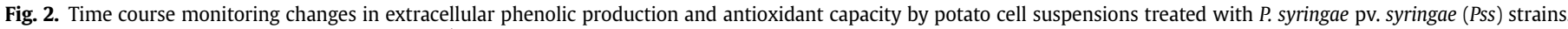

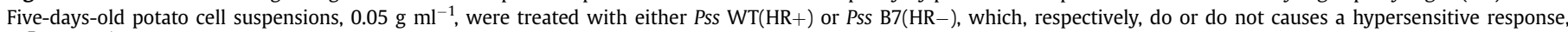

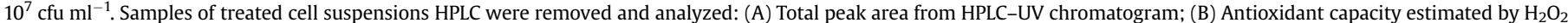

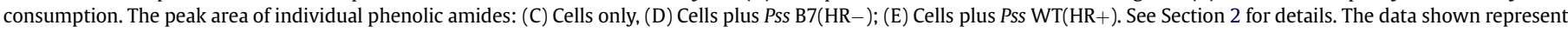

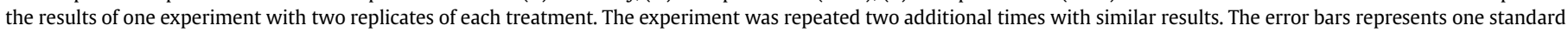
deviation. (FOA, feruloyloctopamine; COA, coumaroyloctopamine; FTA, feruloyltyramine; FMOA, feruloyl-4'-O-methyloctopamine).

extracellular phenolics in this treatment (Fig. 2A) and a decrease between 4 and 6 h.

Four major phenolics, coumaroyloctopamine (COA), feruloyloctopamine (FOA), feruloyltyramine (FTA), feruloyl-4'-Omethyloctopamine (FMOA), were detected in the extracellular fluid of treated 5-days-old potato suspension cells during the $7 \mathrm{~h}$ monitoring period (Fig. 2C-D). In control treatments, FOA was the major constituent and continued to increase throughout the monitoring period while the other constituents fluctuated at lower concentrations (Fig. 2C). In Pss B7(HR-) treatments, the FOA was also the major constituent; COA was the second major constituent and generally increased during the monitoring period (Fig. 2D). COA was the major constituent detected in Pss WT(HR+) treatments and interestingly reached concentrations that were higher than in other treatments after $5 \mathrm{~h}$, which corresponds with the oxidative burst (Fig. 2E).

\subsection{2. $R$. solanacearum and P. tabaci isolates}

Different responses were found when potato cell suspensions were treated with $R$. solanacearum and $P$. tabaci, $10^{7} \mathrm{cfu} \mathrm{ml}^{-1}$, which cause a susceptible and resistant response, respectively, on potato plants. Interestingly, suspensions treated with the $R$. solanacearum maintained relatively low levels of extracellular phenolics compared to untreated cells (Fig. 3A). The antioxidant capacity of the $R$. solanacearum treatment was also much lower than control or P. tabaci treatments (Fig. 3B), which could contribute to the low levels of extracellular phenolics. The lower concentration of extracellular phenolics in the $R$. solanacearum treatments could be attributed to either suppression of phenolic production or an increased oxidative metabolism which oxidizes the phenolics. Both FOA and COA increased to low levels by $4 \mathrm{~h}$, after which COA continued to increase, while FOA began to decrease (Fig. 3C). 

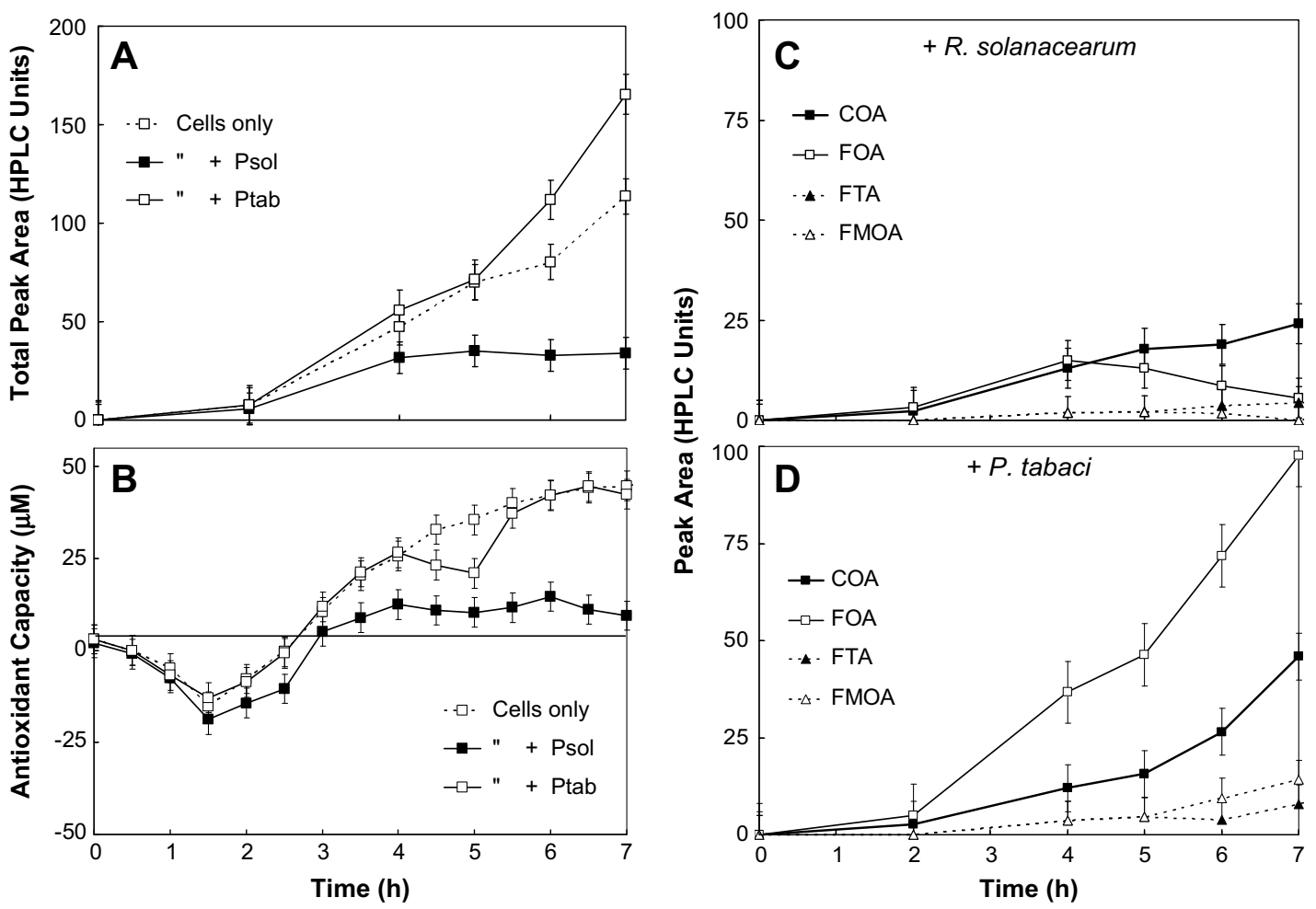

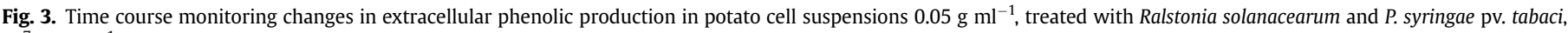

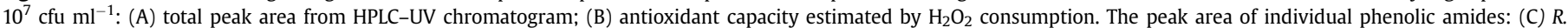

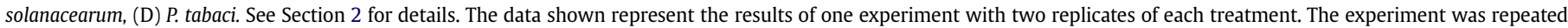

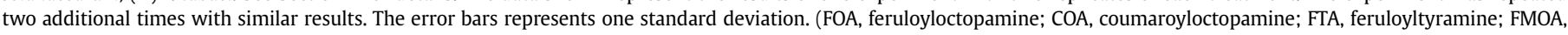
feruloyl-4'-O-methyloctopamine).

Potato suspensions treated with $P$. tabaci accumulated higher levels of phenolics than untreated cells (Fig. 3A). Although P. tabaci caused a small oxidative burst at about $4 \mathrm{~h}$ (Fig. 3B), this did not affect the levels of phenolics that accumulated in this treatment (Fig. 3A,D). Most of the increase in P. tabaci treatments compared to untreated cells was due to increased COA accumulation; the FOA concentrations increased at rates comparable to the untreated cells (Fig. 3C).

\section{Effect of plant cell density and cell age on extracellular phenolic accumulation}

Previous experience with tobacco suspension cells has indicated that both cell density and age affect the quantitative and qualitative aspects of extracellular accumulation [5]. To examine the effect of these parameters on the extracellular phenolic accumulation of either stressed or unstressed potato cell suspensions, the cell density and age of potato suspensions were varied. The extracellular phenolic composition was examined after $6 \mathrm{~h}$. The stress treatment involved the addition of $P$. tabaci, $10^{7} \mathrm{cfu} \mathrm{ml}^{-1}$ for $6 \mathrm{~h}$. The later treatment was chosen because it had demonstrated a large effect on phenolic accumulation (Fig. 3A).

The concentration of extracellular phenolics after $6 \mathrm{~h}$ increased almost linearly as cell density was increased from 0.025 to $0.075 \mathrm{~g} \mathrm{ml}^{-1}$. The individual phenolics feruloyloctopamine (FOA) and coumaroyloctopamine (COA) followed the same pattern for both treated and untreated cells, and appeared to reach a maximum accumulation around $0.075 \mathrm{~g} \mathrm{ml}^{-1}$ (Fig. 4A).

The concentration of extracellular phenolics that accumulated in potato cell suspensions after $6 \mathrm{~h}$ with or without $P$. tabaci, $10^{7} \mathrm{cfu} \mathrm{ml}^{-1}$ increased with the age of the suspension cells (Fig. 4B).
The concentration of feruloyloctopamine and coumaroyloctopamine increased with age in $P$ tabaci treated suspensions, while only feruloyloctopamine increased with age in untreated cells (Fig. 4B).

\section{Effect of bacterial density on extracellular phenolic accumulation}

Previous experience has shown that varying the bacterial density between $10^{7}$ and $10^{8} \mathrm{cfu} \mathrm{ml}^{-1}$ will strongly influence many responses associated with the plant/bacterial interaction $[2,6]$. Therefore we examined its effect on the extracellular phenolic accumulation using 5-days-old potato cells at a cell density of $0.05 \mathrm{~g} \mathrm{ml}^{-1}$ with P. tabaci and $R$. solanacearum (Fig. 5). Changes in the extracellular phenolic amides by potato cells could be seen at bacterial densities of $10^{6} \mathrm{cfu} \mathrm{ml}^{-1}$. As the inoculum concentration of $R$. solanacearum increased to $10^{7} \mathrm{cfu} \mathrm{ml}^{-1}$ the levels of FOA decreased dramatically. The response to increased inoculum concentration of $P$. tabaci caused an initial increase in FOA, at $10^{6} \mathrm{cfu} \mathrm{ml}^{-1}$ followed by $33 \%$ decrease and the inoculum concentration increased to $10^{8} \mathrm{cfu} \mathrm{mL}^{-1}$. Conversely, the COA levels increased as the $P$. tabaci inoculum concentration increased.

\section{Effect of abiotic elicitors on the composition of extracellular phenolics}

Abiotic pathogen-related elicitors are often used to induce responses in plants, such as triggering of gene expression or blocking induction of the hypersensitive response. To see the effect of elicitors on extracellular phenolic amides, we used heat-killed Pss WT(HR+) and a fungal elicitor prepared from $P$. infestans. 

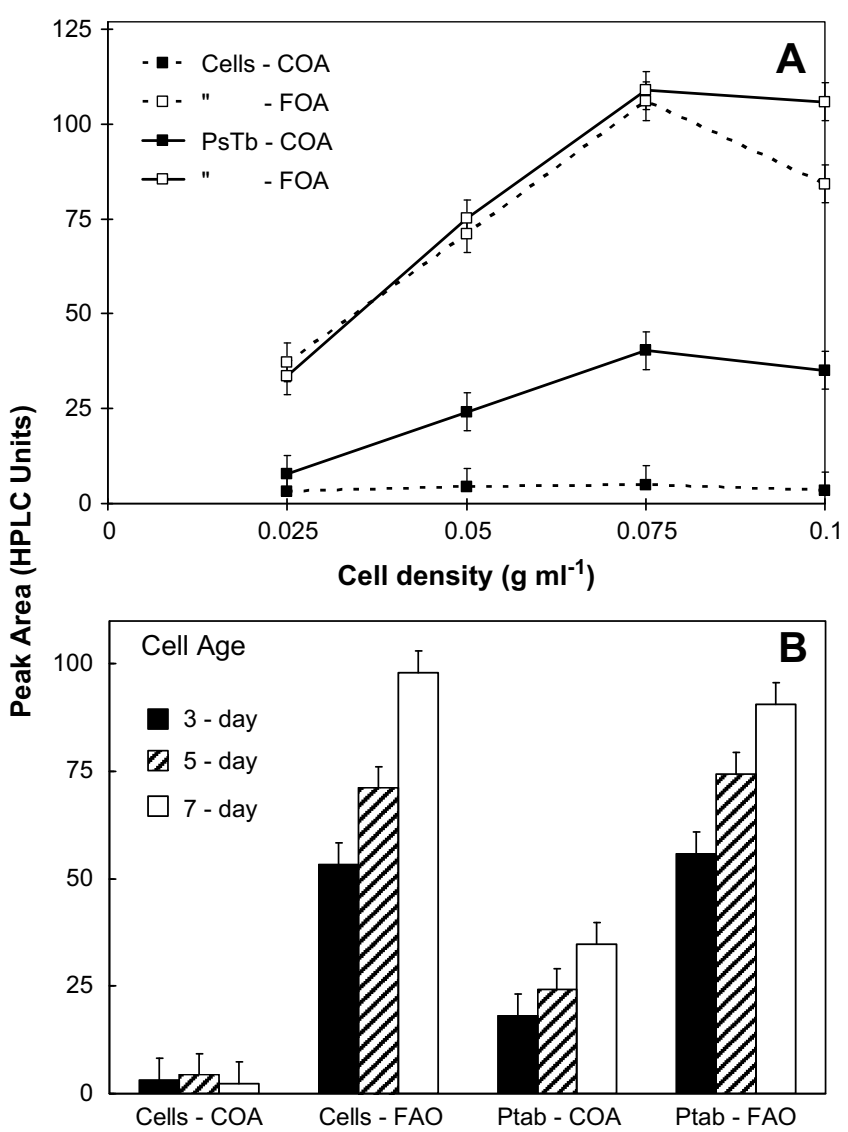

Fig. 4. Effect of cell density and cell age on the composition of extracellular phenolic amides. A. Extracellular phenolic amide composition of potato suspensions, 0.025, $0.05,0.075,0.1 \mathrm{~g} \mathrm{ml}^{-1}$, treated with P. tabaci, $10^{7} \mathrm{cfu} \mathrm{ml}^{-1}$, after $6 \mathrm{~h} \mathrm{~B}$. Extracellular phenolic amide composition of potato suspensions, 3-, 5- and 7-days-old, treated with strain P. tabaci (Ptab), $10^{7} \mathrm{cfu} \mathrm{ml}^{-1}$, for $6 \mathrm{~h}$. The peak area was determined by HPLC-UV. See Section 2 for details. The data shown represent the results of one experiment with two replicates of each treatment. The experiment was repeated two additional times with similar results. The error bars represents one standard deviation. (FOA, feruloyloctopamine; COA, coumaroyloctopamine).

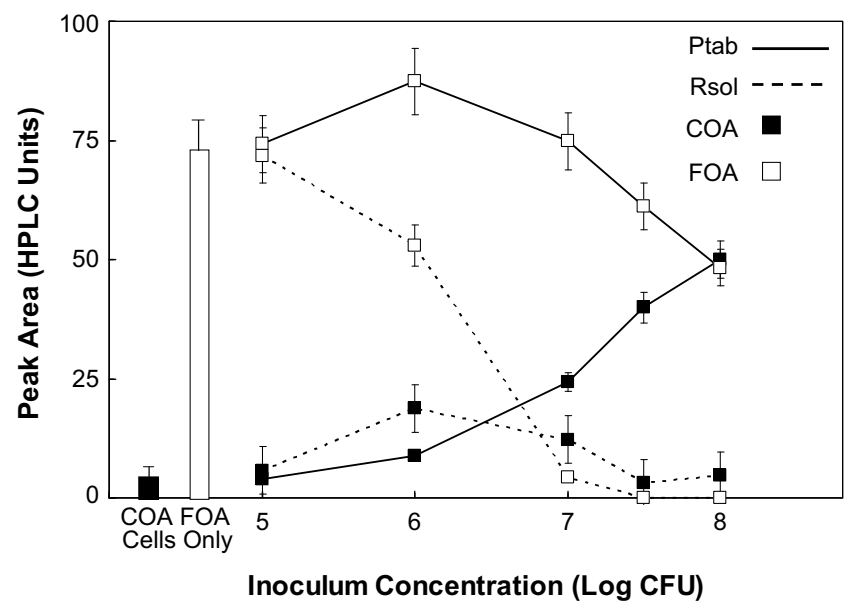

Fig. 5. Effect of the inoculum concentration of bacteria on the composition of extracellular phenolic amides in potato suspensions. Extracellular phenolic composition of 5-days-old potato suspensions treated with designated concentrations of $P$. tabaci (Ptab) or R. solanacearum (Rsol) for $6 \mathrm{~h}$. The peak area was determined by HPLC-UV. See Section 2 for details. The data shown represent the results of one experiment with two replicates of each treatment. The experiment was repeated two additional times with similar results. The error bars represents one standard deviation. (FOA, feruloyloctopamine; COA, coumaroyloctopamine).

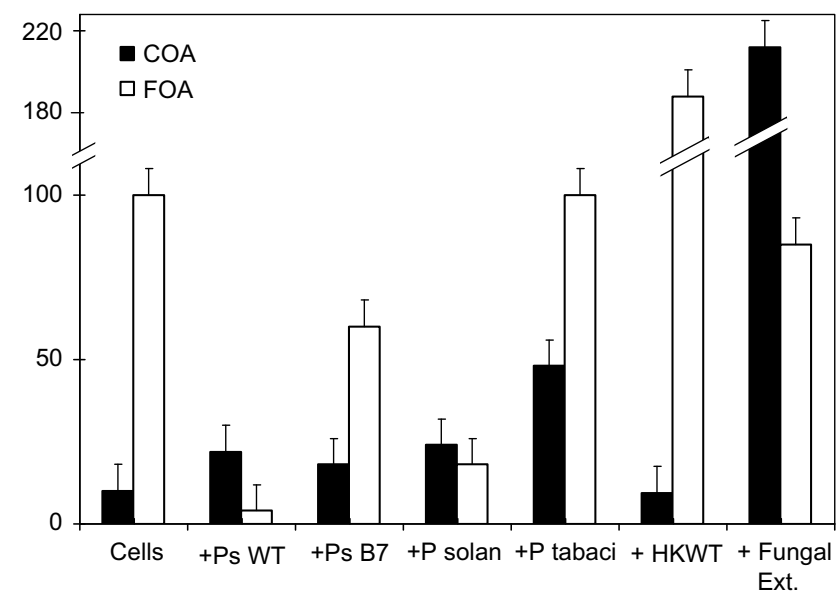

Fig. 6. Comparison of extracellular phenolic amide accumulation in potato suspensions treated with bacteria or pathogen-related elicitors. Five-days-old potato suspensions were treated for $6 \mathrm{~h}$ with the designated bacterial strains, $10^{7} \mathrm{cfu} \mathrm{ml}^{-1}$, heat-killed bacteria (HKWT), or fungal elicitor from Phytophthora infestans. See Section 2 for details. The data shown represent the results of one experiment with two replicates of each treatment. The experiment was repeated two additional times with similar results. The error bars represents one standard deviation. (FOA, feruloyloctopamine; $\mathrm{COA}$, coumaroyloctopamine.

Simultaneous monitoring of antioxidant capacity showed that both elicitors induced an immediate oxidative burst from which the cells recover by $6 \mathrm{~h}$ (data not shown). Despite the oxidative burst that is likely to have oxidized extracellular phenolics in the early phase of incubation, the levels of phenolics increased in potato by $6 \mathrm{~h}$ (Fig. 6). The heat-killed bacteria (HKWT) caused a 2.5 -fold increase in FOA compared to untreated cells, making it the dominant phenolic. The fungal elicitor induced more than a 20 -fold increase in COA, which is normally a minor component, making it the dominant phenol in the extracellular fluid. This was the greatest increase we observed in this study.

This study demonstrates that plant suspension cells actively and rapidly accumulate bioactive phenolics in the extracellular environment during the first several hours of the plant/bacterial interaction. The biotic or abiotic elicitors present determine the magnitude and composition of these phenolics as demonstrated by the results from live and heat-killed bacterial pathogens as well as the $P$. infestans elicitor. It was also demonstrated that these phenolics are redox sensitive and that their concentration will diminish during periods of oxidative stress, which occur during resistant plant/pathogen interactions. Because these phenolics are in direct contact with the bacterial pathogens and because of their reported bioactivity $[16,18,21,24]$ it is feasible to speculate that they could influence the outcome of the interaction, which will be the subject of future studies.

\section{References}

[1] Baker CJ, Atkinson MM, Collmer A. Concurrent loss in Tn5 mutants of Pseudomonas syringae pv. syringae of the ability to induce the hypersensitive response and host plasma membrane $\mathrm{K}+\mathrm{H}+$ exchange in tobacco. Phytopathology 1987;77:1268-72.

[2] Baker CJ, Harmon GL. A noninvasive technique for monitoring peroxidative and $\mathrm{H}_{2} \mathrm{O}_{2}$-scavenging activities during interactions between bacterial plant pathogens and suspension cells. Plant Physiology 1995;108:353-9.

[3] Baker CJ, Mock NM. An improved method for monitoring cell death in cellsuspension and leaf disc assays using Evans Blue. Plant Cell, Tissue and Organ Culture 1994:39:7-12.

[4] Baker CJ, Mock NM. A method to detect oxidative stress by monitoring changes in the extracellular antioxidant capacity in plant suspension cells. Physiological and Molecular Plant Pathology 2004;25:255-61. 
[5] Baker CJ, Mock NM, Whitaker BD, Roberts DP, Rice CP, Deahl KL, et al. Induction of redox sensitive extracellular phenolics during plant-bacterial interactions. Physiological and Molecular Plant Pathology 2005;66:90-8.

[6] Baker CJ, Mock NM, Whitaker BD, Roberts DP, Rice CP, Deahl KL, et al Involvement of acetosyringone in plant-pathogen recognition. Biochemical and Biophysical Research Communications 2005;328:130-6.

[7] Baker CJ, O'Neill NR, Deahl KL, Lydon J. Continuous production of extracellular antioxidants in suspension cells attenuates the oxidative burst detected in plant microbe interactions. Plant Physiology and Biochemistry 2002;40: 641-4.

[8] Dhingra, OD and Sinclair, JB. Basic plant pathology methods. Boca Raton, pp. 434: CRC Press; 85

[9] Edreva AM, Velikova VB, Tsonev TD. Phenylamides in plants. Russian Journal of Plant Physiology 2007;54:287-301.

[10] Facchini PJ, Hagel J, Zulak KG. Hydroxycinnamic acid amide metabolism: physiology and biochemistry. Canadian Journal of Botany 2002;80:577-89.

[11] Hagel JM, Facchini PJ. Elevated tyrosine decarboxylase and tyramine hydroxycinnamoyltransferase levels increase wound-induced tyramine-derived hydroxycinnamic acid amide accumulation in transgenic tobacco leaves. Planta 2005;221:904-14.

[12] Hahlbrock K, Bednarek P, Ciolkowski I, Hamberger B, Heise A, Liedgens $\mathrm{H}$, et al Non-self recognition, transcriptional reprogramming, and secondary metabolite accumulation during plant/pathogen interactions. Proceedings of the National Academy of Sciences of the United States of America 2003;100:14569-76.

[13] Hahlbrock K, Scheel D. Physiology and molecular biology of phenylpropanoid metabolism. Annual Review Plant Physiology Plant Molecular Biology 1989;40:347-69.

[14] Kamoun S, Young M, Forster H, Coffey MD, Tyler BM. Potential role of elicitins in the interaction between Phytophthora species and tobacco. Applied and Environmental Microbiology 1994;60:1593-8.
[15] Keller H, Hohlfeld H, Wray V, Hahlbrock K, Scheel D, Strack D. Changes in the accumulation of soluble and cell wall-bound phenolics in elicitor-treated cell suspension cultures and fungus-infected leaves of Solanum tuberosum. Phytochemistry 1996;42:389-96.

[16] Lee Y, Jin S, Sim W, Nester E. The sensing of plant signal molecules by Agrobacterium: genetic evidence for direct recognition of phenolic inducers by the VirA protein. Gene 1996;179:83-8.

[17] Matsuda F, Morino K, Ano R, Kuzawa M, Wakasa K, Miyagawa H. Metabolic flux analysis of the phenylpropanoid pathway in elicitor-treated potato tuber tissue. Plant and Cell Physiology 2005;46:454-66.

[18] Mo Y, Geibel M, Bonsall RF, Gross DC. Analysis of sweet cherry (Prunus avium L.) leaves for plant signal molecules that activate the syrB gene requried for synthesis of the phytotoxin, syringomycin, by Pseudomonas syringae pv. syringae. Plant Physiol 1995;107:603-12.

[19] Muhlenbeck U, Kortenbusch A, Barz W. Formation of hydroxycinamoylamides and alpha-hydroxyacetovanillone in cell cultures of Solanum khasianum. Phytochemistry 1996;42:1573-9.

[20] Negrel J, Martin C. The biosynthesis of feruloyltyramine in Nicotiana tabacum. Phytochemistry 1984;23:2797-801.

[21] Peters NK, Frost JW, Long SR. A plant flavone, luteolin, induces expression of Rhizobium meliloti nodulation genes. Science 1986;233:977-80.

[22] Schmidt A, Scheel D, Strack D. Elicitor-stimulated biosynthesis of hydroxycinnamoyltyramines in cell suspension cultures of Solanum tuberosum. Planta 1998;205:51-5.

[23] Soylu S, Soylu EM. Preliminary characterization of race-specific elicitors from Peronospora parasitica and their ability to elicit phenolic accumulation in Arabidopsis. Phytoparasitica 2003;31:381-92.

[24] Von Roepenack-Lahaye E, Newman M-A, Schornack S, Hammond-Kosack KE, Lahaye T, Jones JDG, et al. p-Coumarolynoradrenaline, a novel plant metabolite implicated in tomato defense against pathogens. Journal of Biological Chemistry $2003 ; 278: 43373-83$. 